\title{
Tykktarmskreft, immunmodulering og acetylsalisylsyre
}

\author{
Adjuvant acetylsalisylsyre og utvidet metastasekirurgi bidrar til økt over- \\ levelse blant pasienter med tykktarmskreft.
}

Hvert år diagnostiseres 4000 mennesker med tykktarmskreft i Norge, og overlevelsen er ca. $40 \%$. I mitt forskningsarbeid har vi konsentrert oss om behandlingsstrategier hos pasienter med tykktarmskreft, i tillegg til hvordan kreft utvikles i samspill med immunforsvaret.

Vi utførte en retrospektiv studie som koblet data fra Kreftregisteret med Reseptregisteret, med 25644 pasienter med tykktarmskreft, og vi fant at de 6109 som brukte acetylsalisylsyre, hadde 16-25\% økt overlevelse. I tillegg utførte vi en kohortstudie med 239 pasienter med metastatisk tykktarmskreft, hvor vi fant at neoadjuvant kjemoterapi og en pågående tilnærming til å fjerne metastatisk sykdom bidrar til økt overlevelse.
Jeg har også utført to laboratoriestudier hvor jeg så på immunmodulering. Økt antall regulatoriske T-celler er relatert til dårligere prognose for mange krefttyper, og jeg fant en ny markør for regulatoriske T-celler, CD147, som identifiserer en aktivert og mer suppressiv type. Jeg utførte også en studie hvor jeg så på immunhemmende faktorer $i$ ascites fra pasienter med eggstokkreft, hvor jeg fant at ascites hemmer T-celler.

De kliniske funnene underbygger tidligere arbeider og kan føre til endret praksis, mens laboratoriefunnene bidrar til økt forståelse av samspillet mellom tumorer og immunitet.

Simer Jit Bains

simerjb@gmail.com

\section{Koronar genekspresjon og leukocyttaktivering}

\section{Ved hjerteinfarkt foreligger dynamiske endringer i koronar genekspre- sjon og aktivering av nøytrofile granulocytter.}

Akutt hjerteinfarkt behandles prinsipielt likt hos alle med åpning av den tette hjertekransåren og med medikamenter som hemmer blodplate- og koagulasjonsaktivering, og eventuelt akselererer fibrinolyse.

Ettersom hjerteinfarkt ofte medfører hjertesvikt og død er inngående kunnskap om bakenforliggende patofysiologi og dertil mulighet for mer skreddersydd behandling viktig.

Gjennom vårt arbeid har vi funnet at koronare tromber fra pasienter med akutt hjerteinfarkt uttrykker en profil for genetisk regulering av proteiner som endrer seg ut fra hvor lenge man har hatt brystsmerter, men også ut fra om man har diabetes type 2 eller hypertensjon. Ettersom nivå av sirkulerende proteiner ikke samsvarer med uttrykk av tilsvarende gener i de koronare trombene, er prosessen som finner sted i trombene sannsynligvis svært lokal. Videre ser det ut til at akutt hjerteinfarkt involverer den undergruppen av hvite blodceller man inntil nylig har trodd har hatt sin viktigste funksjon innen infeksjons- og betennelsesprosesser - nemlig nøytrofile granulocytter, samt at nivå av markører for sirkulerende nøytrofile granulocytter til en viss grad kan predikere infarktstørrelse.

Verken dynamiske forhold i koronare tromber eller aktivering av nøytrofile granulocytter angripes spesifikt i dagens hjerteinfarktbehandling. Hvorvidt det er mulig å gi mer individualisert behandling basert på symptomvarighet eller satse på mer generell «antibetennelsesrettet» strategi, gjenstår å se.

\section{Ragnhild Helseth}

ragnhild.helseth@gmail.com

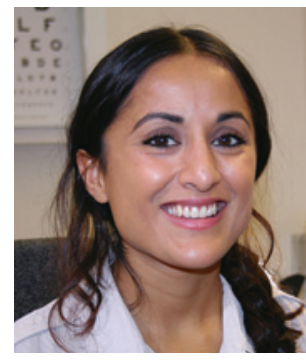

Simer Jit Bains. Foto: Joakim Thoresen

\section{Disputas}

Simer Jit Bains disputerte for ph.d.-graden ved Universitetet i Oslo 29.1. 2016. Tittelen på avhandlingen er Malignancy, metastasis and immune system.

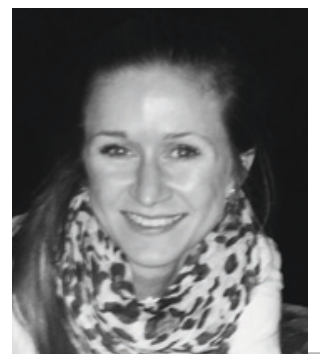

Ragnhild Helseth Foto: Privat

\section{Disputas}

Ragnhild Helseth disputerte for ph.d.-graden ved Universitetet i Oslo 26.11. 2015. Tittelen på avhandlingen er Coronary thrombus genes and neutrophil cell activation in acute myocardial infarction. 